\section{Vital Pulp Therapies in Clinical Practice: Findings from a Survey with Dentist in Southern Brazil}

Luiz Alexandre Chisini ${ }^{1}$, Marcus Cristian Muniz Conde ${ }^{1}$, Marcos Britto Correa ${ }^{1,2}$, Raquel Venâncio Fernandes Dantas ${ }^{1}$, Adriana Fernandes Silva ${ }^{1}$, Fernanda Geraldes Pappen', Flávio Fernando Demarco ${ }^{1,2}$

\author{
'Post-Graduate Program in \\ Dentistry, School of Dentistry, \\ UFPel - Universidade Federal de \\ Pelotas, Pelotas, RS, Brazil \\ ${ }^{2}$ Post-Graduate Program in \\ Epidemiology, UFPel - Universidade \\ Federal de Pelotas, Pelotas, Brazil
}

Correspondence: Flávio Fernando Demarco: 457, Rua Gonçalves Chaves $5^{\circ}$ andar, 96015-560 Pelotas, RS, Brasil. Tel: +55-53-8111-2528. e-mail: ffdemarco@gmail.com

\begin{abstract}
Studies based on dentists' clinical practice possess vital relevance to understand factors leading the clinicians to choose by a specific technique over another. This study investigated which clinical conduct therapies are adopted by dentists in front of deep caries. Was evaluated how the place of work, post-graduate training and years since complete graduation influenced their decisions. A cross-sectional study was performed using a self-applied questionnaire with dentists $(n=276)$ in Southern Brazil. Information regarding post-graduation training (specialization, master's or $\mathrm{PhD}$ ), clinical experience (years since completing graduation) and place of work were investigated. The information regarding pulp vital therapies (materials for direct pulp capping; techniques for caries removal in deep cavities and strategies for indirect pulp capping) were collected by specific questions. Data were submitted to descriptive analysis and Exact Fischer Test. Response rate was $68 \%$ (187). The majority of dentists selected the calcium hydroxide $(\mathrm{CH})$ as first material for direct $(86.3 \%)$ and indirect $(80.3 \%)$ pulp protection. Partial caries removal was reported by $61.9 \%$ of dentists. Less experienced clinical dentists choose partial caries removal more frequently $(p=0.009)$, if compared with dentists graduated 10 years and up ago. The use of MTA was more common among professionals working at academic environment. Besides, MTA was not mentioned by professionals working exclusively in the public health service $(\mathrm{p}=0.003)$. In conclusion, the time since graduation influenced the clinical conduct related to caries removal. The choice of liner materials was influenced by dentists' workplace.
\end{abstract}

Key Words: dentists patient relations, survey, caries removal, pulp protection, cross-sectional studies

\section{Introduction}

Dental pulp has a series of biological activities, including protection, nutrition, sensitivity and formative capacity, and the maintenance of pulp vitality should be an ultimate goal of restorative treatments to the injured teeth (caries, trauma) (1). The diagnosis of pulp condition plays a crucial role when indicating pulp vital therapies, since the success of such treatments may only be achieved in cases of reversible pulpitis (2). However, diagnosing the pulp vitality is a complex task due the subjective nature of symptoms and tests carried out for this purpose. Generally, the diagnosis relies on pulp vitality tests, comprising radiographic evaluation, percussion, palpation and thermal tests, but these tests have an estimated subjective accuracy (3). The main reason for vital pulp therapies failure has been related to pulp complications due to poor diagnoses (1).

Caries, especially deep lesions, may produce significant damage to the pulp tissue (1). There are several different approaches to treat carious teeth in order to preserve the pulp vitality, including stepwise excavation; indirect and direct pulp protection, and pulpotomy $(4,5)$. Historically, it was recommended that all the carious teeth should be removed from the cavities, even in the eminence of a pulp exposure. Total caries removal may result in pulp exposure affecting negatively the prognoses of Pulp Vital Therapies (2) since the contamination of remaining pulp tissue hinders the ability of the pulp to heal (3).

Because of this, the partial caries removal, in techniques like the stepwise excavation, could provide an environment for pulp recovering and dentin formation $(2,4)$. Despite these promising results with the partial removal of carious tissue, a high proportion of the dentists may still prefer in the imminent risk of a pulp exposure to remove all the carious dentin (2). Even tough, the avoidance of pulp exposure could contribute to a better prognosis; in some situations, this exposition could be inevitable and a material should be applied on the exposed pulp to provide an enhanced environment for recovering (6). For several decades, calcium hydroxide (CH)-based materials were the first choice for capping the exposed pulp, with clinical studies observing pulp healing and dentin bridge formation in permanent teeth (7). However, in more recent years, mineral trioxide aggregate - MTA has been proposed as an alternative for $\mathrm{CH}$, showing a great ability to maintain the integrity of the pulp tissues with low inflammation, hyperemia and pulp necrosis (8). 
Another aspect that could interfere with the possibility of pulp healing is the restorative procedure (9). Currently composite resin restorations are considered the first choice material for anterior and posterior teeth (10). Once that composites may depict toxicity with the pulp tissue, especially in deep cavities (11), there is the recommendation to use some protective materials, such as $\mathrm{CH}$ cements or glass ionomer cements, prior the application of adhesive systems and composite resins (12).

Studies based on dentists' clinical practice possess paramount relevance to understand factors influencing the clinicians choice of a specific technique over another (13). Therefore, several studies have been published in the literature evaluating dentists' preferences in relation to different restorative procedures, demonstrating that the time since graduation, the place of work and the attendance to post-graduate programs, could influence the options selected by these dentists (14-16).

Therefore, the aim of this study was to investigate the restorative options of dentists about direct pulp protection, caries removal technique and pulp protection under composite restorations. Additionally, it was assessed whether time of clinical experience or post-graduate training influenced these options.

\section{Material and Methods}

This study had the approval of the Ethics Committee, School of Dentistry, Federal University of Pelotas. It consists in a cross-sectional study performed in the city of Pelotas, Southern Brazil, between March and June 2009. Dentists registered ( $n=276)$ in the Brazilian Dentistry Council, section of Pelotas, constituted the population for the study.

Data were collected using self-applied closed questionnaires, which included demographic information (sex), professional characteristics, and information regarding operative dentistry procedures, in this particular study those related to removal of carious dentin (partial or complete), materials for direct pulp capping ( $\mathrm{CH}, \mathrm{MTA}$ or other) and protective materials for composite restorations in deep caries lesions ( $\mathrm{CH}$, glass ionomer cement, adhesive systems and their combinations). These questions and their respective response options are described in Table 1. The questionnaire did not include information that enabled the identification of any of the dentists, and it was pretested with professionals who were not involved in the study. Time since graduation was collected in years and categorized in "up to 10 years" and "more than 10 years". Individuals were asked about their level of specialization and divided in general practitioners (without additional post-graduation) and specialists, when they have attended a specialization course (certificate) or have a master or $\mathrm{PhD}$ degree. The place of work was also assessed and divided in "private office", "public service", "both public and private services" and "university".

The questionnaires were personally delivered to each dentist, and the importance of participation as well as the

Table 1. Questions related to the vital pulp therapies

1 - In cases of deep decay lesion when pulp proximity is present, what would be your option to treat this lesion?

(0) Total removal of the caries lesion, independent of pulp exposition risk, temporary restoration, which should be replaced by definitive restoration in other clinical session

(1) Total removal of caries lesion, independent of pulp exposition risk, followed by definitive restoration in the same clinical session

(2) Partial removal of carious dentin in the bottom of the cavity and a temporary restoration, which should be followed by definitive restoration in another clinical session

(3) Partial removal of carious dentin in the bottom of the cavity and a definitive restoration, in the same clinical session

2 - In cases of a deep cavity that will be restored with composite resin, how would you proceed to protect the pulp:

(0) $\mathrm{CH}$ cement + adhesive system + composite resin

(1) $\mathrm{CH}$ cement + glass ionomer cement + adhesive system + composite resin

(2) Glass ionomer cement+ adhesive system+ composite resin

(3) Adhesive system + composite resin

3 - In cases where the tooth has pulp vitality and the pulp was exposed, which material you choose for direct protection aiming to produce the best biological results (pulp repair, with dentin bridge formation)?

(0) $\mathrm{CH}$ powder or paste

(4) $\mathrm{CH}$ cement

(1) Zinc oxide with eugenol cement

(5) MTA

(2) Portland cement

(6) Adhesive system

(3) None; endodontic treatment 
aim of the study was enlightened to each professional. After one week, in a second visit to the dental offices, the questionnaires were recovered, together with the signed

Table 2. Number of observations and frequencies of the studied variables among dentists. Pelotas, Brazil $(n=187)$

\begin{tabular}{|c|c|c|}
\hline Variable & $\mathrm{n}^{*}$ & $(\%)$ \\
\hline Sex & 187 & \\
\hline Male & 89 & 47.6 \\
\hline Female & 98 & 52.4 \\
\hline Place of work & 183 & \\
\hline Private & 118 & 64.5 \\
\hline Public & 17 & 9.3 \\
\hline Private and Public & 22 & 12.0 \\
\hline University & 26 & 14.2 \\
\hline Time since graduation & 176 & \\
\hline$\leq 10$ years & 75 & 42.6 \\
\hline$>10$ years & 101 & 57.4 \\
\hline Post-graduation training & 185 & \\
\hline General Dentistry Practitioner & 64 & 34.6 \\
\hline Specialist/MMD/PhD & 121 & 65.4 \\
\hline Caries removal & 171 & \\
\hline \multicolumn{3}{|l|}{ Total caries excavation } \\
\hline Temporary Restoration & 56 & 32.8 \\
\hline Definitive Restoration & 9 & 5.3 \\
\hline \multicolumn{3}{|l|}{ Partial caries excavation } \\
\hline Temporary Restoration & 100 & 58.5 \\
\hline Definitive Restoration & 6 & 3.4 \\
\hline Pulp protection for deep composite restorations & 172 & \\
\hline $\mathrm{CH}$ Cement $+\mathrm{AS}+\mathrm{CR}$ & 19 & 11.1 \\
\hline $\mathrm{CH}$ Cement $+\mathrm{GlC}+\mathrm{AS}+\mathrm{CR}$ & 119 & 69.2 \\
\hline $\mathrm{GlC}+\mathrm{AS}+\mathrm{CR}$ & 28 & 16.3 \\
\hline $\mathrm{AS}+\mathrm{CR}$ & 2 & 1.1 \\
\hline 1 don't do composite resin restorations & 4 & 2.3 \\
\hline Material for direct pulp capping & 175 & \\
\hline $\mathrm{CH}$ & 151 & 86.3 \\
\hline MTA & 11 & 6.3 \\
\hline $\mathrm{CH}$ and MTA & 8 & 4.6 \\
\hline Other materials than $\mathrm{CH}$ and MTA & 5 & 2.8 \\
\hline
\end{tabular}

*Total number of valid observations. Fisher's Exact test. OS = One clinical session. $\mathrm{AS}=$ Adhesive system. $\mathrm{CR}=$ Composite resin. $\mathrm{GIC}=$ Glass ionomer cement informed consent to participate in the study. If the dentists did not return the questionnaire after two consecutive visits, they were considered to be dropouts.

Data were recorded to carry out descriptive analyses, and the association with time since graduation, place of work, and attendance of post-graduation training courses was tested with Fisher's exact test. The analyses were done with Stata 10.0 (StataCorp, College Station, TX, USA) software package. A level of significance of $p \leq 0.05$ and confidence interval of $95 \%$ was calculated.

\section{Results}

From the total number of dentists included in the sample size, 187 (68\%) participated in the study. The losses and refusals were mainly due to the lack of questionnaire return or failure to sign the informed consent form. Since the questionnaire was self-applied, some clinicians failed to answer all the questions, and accordingly the number of answers for each question presented variations.

Descriptive analysis is presented in Table 2 . In relation to sex, $52.4 \%$ were female, and among the participating dentists $42.6 \%$ had been graduated up to 10 years ago. From the total number of responding dentists, $65.4 \%$ had been enrolled in some kind of formal post-graduation training (i.e., masters or $\mathrm{PhD}$ degrees, specialized courses). Regarding deep caries lesions excavation, $61.4 \%$ of clinicians affirmed to perform partial caries removal. Moreover, $80.3 \%$ reported to use $\mathrm{CH}$ cement when restoring a deep cavity with composite resin. For direct pulp capping, the first choice material was $\mathrm{CH}$ in different forms of application (powder, paste or cement) with $86.3 \%$.

In Table 3, it is possible to observe the association of time since graduation and the 3 questions related to pulp therapies. The only association observed was that younger professionals (graduated up to ten years) tend to perform partial caries removal more frequently, when compared with dentists graduated up to 10 years ago $(p=0.009)$.

In relation to the association with place of work (Table 4), despite $\mathrm{CH}$ being the most used liner, the use of MTA was more common among professionals working at academic environment. Professionals working only in the public health service did not mention the use of MTA.

In relation to the post-graduation training, no significant association was found with any of the questions about pulp therapies.

\section{Discussion}

The overall results of this study showed that the dentist characteristics (time in clinical practice and place of work) influenced their decisions in relation to the pulp therapies approaches evaluated.

Untreated caries in permanent teeth is the main public 
oral health problem (17), therefore caries removal is an activity performed frequently by the dentists in daily practice. However, there is no specific parameter regarding excavation depth, technique, or suitable diagnostic criteria or aids for caries removal (4). In relation to carious dentin removal, more than $60 \%$ of the professionals preferred to perform the partial removal (most of them followed by a temporary restoration). Recent data (18) have demonstrated that partial caries removal in deep carious lesions provides a good environment for pulp recovering.

Dentists with up to 10 years since their graduation were more likely to carry out partial removal compared to those with higher time in clinical practice. The concept of partial caries removal is more recent than the complete caries removal and part of the dentists with more years since their graduation may not be familiarized with this concept. Even though the evidence based dentistry has become a growing concern in dentistry, the dental professional still relies on results from their clinical routine, attributing reliability for techniques based on their own clinical experience (19). In another study, performed with dentists working in Public Health Systems in Southern Brazil (20), the authors also detected that those graduated more recently were more prone to indicate the partial removal of caries, corroborating our results.

Almost $40 \%$ of the dentists included have selected the complete removal of carious dentin, even with the risk of pulp exposure. The exposition of the pulp is a critical point that can conduct to an unfavorable response, leading to a low success rate for direct pulp protection or pulpotomy (3). When the pulp is exposed, and there is an indication to protect such tissue, $\mathrm{CH}$-based materials and MTA are applied (8). In cases of pulp exposure, an expressive percentage $(86.3 \%)$ of the responding dentists opted for the $\mathrm{CH}$-based materials. There are some concerns related to the direct application of $\mathrm{CH}$-based materials, including the potential occurrence of tunnels in the dentin bridges or the dissolution of the material under the restoration (11). MTA could present better clinical results than $\mathrm{CH}-$ based materials (8), producing the formation of dentin barriers with lower level of initial inflammatory response (12). In our study, MTA was selected by a low rate of dentist, when applied alone or in combination with $\mathrm{CH}$ based materials. In such context, it could be observed that the working place influenced the decision regarding the direct pulp capping material. The higher proportion of use of MTA instead of $\mathrm{CH}$ was found in professionals working in the University environment. Such professionals are more likely to be updated with the current literature and they could be informed about the potentially better outcome presented for MTA in direct pulp capping. In opposite, none of the evaluated dentists working exclusively in the public health system chooses MTA as the capping material (100\% selected calcium hydroxide). In fact, MTA is far more expensive than $\mathrm{CH}$-based materials and it is not available in the majority of the basic units in the public system. The price of the product and the lack of information regarding the promising results related to MTA could explain its low indication for dentists in private practice.

In relation to the pulp protection for composite restorations in deep cavities, almost $70 \%$ of the responding dentists recommended the placement of calcium hydroxide in deep part of the cavity, followed by the application of glass ionomer cement. There are concerns in relation to

Table 3. Association between the time of clinical practice (since graduation) of dentists and variables related to practices for pulp therapies. Pelotas, Brazil $(n=187)$

\begin{tabular}{|c|c|c|c|}
\hline & \multicolumn{2}{|c|}{ Clinical practice $-\mathrm{n}^{*}(\%)$} & \multirow{2}{*}{$\mathrm{p}$ value } \\
\hline & $\leq 10$ years & $>10$ years & \\
\hline $\begin{array}{l}\text { Techniques for caries } \\
\text { removal in deep cavities }\end{array}$ & & & 0.009 \# \\
\hline \multicolumn{4}{|l|}{ Total caries excavation } \\
\hline Temporary restoration & 23(31.9) & $29(33.0)$ & \\
\hline Definitive restoration & $0(0.0)$ & $9(10.2)$ & \\
\hline \multicolumn{4}{|l|}{ Partial caries excavation } \\
\hline Temporary restoration & $45(62.5)$ & $49(55.7)$ & \\
\hline Definitive restoration & $4(5.6)$ & $1(1.1)$ & \\
\hline $\begin{array}{l}\text { Pulp protection for deep } \\
\text { composites restorations }\end{array}$ & & & 0.368 \\
\hline $\mathrm{CH}$ Cement + AS + CR & $7(9.5)$ & $12(13.8)$ & \\
\hline $\mathrm{CH}$ Cement $+\mathrm{GlC}+\mathrm{AS}+\mathrm{CR}$ & $50(67.6)$ & $62(71.3)$ & \\
\hline $\mathrm{GlC}+\mathrm{AS}+\mathrm{CR}$ & 15(20.3) & $9(10.3)$ & \\
\hline $\mathrm{AS}+\mathrm{CR}$ & $1(1.3)$ & $1(1.1)$ & \\
\hline 1 do not use composite resin & 1(1.3) & $3(3.5)$ & \\
\hline Material for direct pulp capping & & & 0.454 \\
\hline $\mathrm{CH}$ & $60(82.2)$ & $82(90.1)$ & \\
\hline MTA & $6(8.2)$ & $5(5.5)$ & \\
\hline $\mathrm{CH}$ and MTA & $3(5.5)$ & $1(3.3)$ & \\
\hline Other material than $\mathrm{CH}$ and MTA & $4(4.1)$ & $3(1.1)$ & \\
\hline
\end{tabular}

\# Statistically significant difference. * Total number of valid observations. Fisher's Exact test. $\mathrm{OS}=$ One clinical session. $\mathrm{AS}=$ Adhesive system. $\mathrm{CR}=$ Composite resin . $\mathrm{GlC}=$ Glass ionomer cement 
the application of adhesive systems and GIC directly in the deepest portion of the cavity due to the potential toxicity that could be observed with these products $(11,21)$. The application of such materials could be associated with the idea that an intermediate material can provide a better environment for pulp healing, by avoiding the penetration of unreacted monomers and acids from GIC, which could penetrate dentin causing chronic inflammation or even pulp necrosis (11). It is important to highlight that a systematic review and meta-analysis failed to show clear evidence in relation to the superiority of calcium hydroxide over resinmodified glass ionomer cements in deep cavities (21). Even considering that total etch technique, without the use of a layer of intermediate material could function well in anterior and posterior teeth (10), the high proportion of dentists selecting glass ionomer cement as an intermediate material might indicate that dentists are still believing in the proposed benefits of its application under composite restorations (22).
This study was part of a large questionnaire survey investigating the dentists' preferences in relation to a series of different treatment techniques (14-16,23). In the present study, the post-graduation training was not significantly associated with any of the outcomes (questions) related to vital pulp techniques. In this sample of dentists, previous reports showed that the post-graduation training has affected the choice for vital bleaching treatment (16), use of rubber dam for composite restoration (14), the selection of adhesive system (15) or the choice of post for endodontically treated teeth (23). The authors of these studies have pointed out that dentists attending to post-graduation training could be more updated with the recent literature and would prefer to select options with stronger scientific evidence. Nevertheless, this influence was not observed in the present study in relation to pulp therapy questions.

Some limitations could also be highlighted for this survey. There were more than $30 \%$ of the dentists included in the sample size that refused or failed to participate in the study. The losses and refusals were mainly due to the lack of questionnaire return or failure to sign the informed consent form. However, the response rate (68\%) was higher than similar studies investigating treatment options among dentist in clinical practice $(5,20)$. Was applied a self-applied questionnaire and some dentists did not answer all the questions, making the numbers of respondents different for each question, but the number of non-answered questions was bellow $10 \%$. Also, was applied this approach, because it would the best way to deliver the questionnaire without disrupt the organization of the clinical practice.

The results of the present study demonstrated that partial caries removal was the preferred approach to deal with deep carious lesions, the vast majority of dentists selected calcium hydroxide as the direct capping material and most of the dentists preferred to use a combination of materials to protect the pulp in case of deep cavities restored with composite. The time since graduation and the working

"Statistically significant difference. * Total number of valid observations. Fisher's Exact test. OS = One clinical session. $\mathrm{AS}=$ Adhesive system $. \mathrm{CR}=$ Composite resin. $\mathrm{GIC}=$ Glass ionomer cement 
place influenced the choice of the dentists that answered the survey.

\section{Resumo}

Estudos baseados na prática clínica de dentistas possuem relevância vital para o entendimento dos fatores que influenciam os clínicos na escolha de uma técnica especifica em detrimento de outra. Este estudo investigou quais condutas clínicas são adotadas por dentistas frente a lesões profundas de cárie. Foi avaliado como o local de trabalho, curso de pós-graduação e tempo desde a graduação influenciaram suas decisões clínicas. Foi conduzido um estudo transversal utilizando questionários auto- aplicados à dentistas no sul do Brasil ( $\mathrm{n}=276)$. Informações relacionadas a educação continuada (especialização, mestrado ou doutorado), experiência clínica (anos desde a graduação) e local de trabalho foram investigadas. As informações sobre terapias vitais da polpa (materiais para capeamento pulpar direto, técnicas para remoção de carie em cavidades profundas e estratégias para capeamento pulpar indireto) foram coletadas por meio de perguntas específicas. Os dados foram submetidos à análise descritiva e teste exato de Fisher. A taxa de resposta foi de $68 \%$ (187). A maioria dos dentistas selecionam o hidróxido de cálcio $(\mathrm{HC})$ como primeiro material para proteção pulpar direta $(86,3 \%)$ e indireta $(80,3 \%)$. Remoção parcial de tecido cariado foi relatado por $61,9 \%$ dos clínicos. Dentistas com menor experiência clínica optaram pela remoção parcial de tecido cariado com mais frequência $(p=0,009)$, quando comparados a dentistas graduados há mais de 10 anos. 0 uso do MTA foi mais comum entre os profissionais que trabalham em ambiente acadêmico. Além disso, o MTA não foi mencionado pelos profissionais que trabalham exclusivamente no serviço público de saúde $(p=0,003)$. 0 tempo desde a graduação influenciou a conduta clínica relacionada à remoção de cárie. A escolha de materiais para proteção pulpar foi influenciada pelo local de trabalho dos dentistas.

\section{References}

1. Bjorndal L, Mjor IA. Pulp-dentin biology in restorative dentistry. Part 4: Dental caries--characteristics of lesions and pulpal reactions. Quintessence Int 2001;32:717-736.

2. Maltz M, Alves LS. Incomplete caries removal significantly reduces the risk of pulp exposure and post-operative pulpal symptoms. Journal of Evidence-Based Dental Practice 2013;13:120-122.

3. Aguilar $P$, Linsuwanont $P$. Vital pulp therapy in vital permanent teeth with cariously exposed pulp: a systematic review. J Endod 2011;37:581587.

4. Ricketts DN, Kidd EA, Innes N, Clarkson J. Complete or ultraconservative removal of decayed tissue in unfilled teeth. Cochrane Database of Systematic Reviews 2006:CD003808.

5. Schwendicke F, Meyer-Lueckel H, Dorfer C, Paris S. Attitudes and behaviour regarding deep dentin caries removal: a survey among German dentists. Caries Res 2013;47:566-573.

6. Hilton TJ, Ferracane JL, Mancl L. Northwest Practice-Based Research Collaborative in Evidence-Based D. Comparison of $\mathrm{CaOH}$ with MTA for direct pulp capping: a PBRN randomized clinical trial. J Dent Res 2013;92:16S-22S.

7. Witherspoon DE. Vital pulp therapy with new materials: new directions and treatment perspectives--permanent teeth. J Endod
2008;34:S25-S28

8. Li Z, Cao L, Fan M, Xu Q. Direct pulp capping with calcium hydroxide or mineral trioxide aggregate: A meta-analysis. J Endod 2015;41:14121417.

9. Demarco FF, Rosa MS, Tarquinio SB, Piva E. Influence of the restoration quality on the success of pulpotomy treatment: a preliminary retrospective study. Journal of Applied Oral Science 2005;13:72-77.

10. Baldissera RA, Correa MB, Schuch HS, Collares K, Nascimento GG, Jardim PS, et al.. Are there universal restorative composites for anterior and posterior teeth? J Dent 2013;41:1027-1035.

11. Elias RV, Demarco FF, Tarquinio SB, Piva E. Pulp responses to the application of a self-etching adhesive in human pulps after controlling bleeding with sodium hypochlorite. Quintessence Int 2007;38:e67-77.

12. Bjorndal $L$, Reit $C$, Bruun G, Markvart M, Kjaeldgaard M, Nasman $P$, et al.. Treatment of deep caries lesions in adults: randomized clinical trials comparing stepwise vs. direct complete excavation, and direct pulp capping vs. partial pulpotomy. Eur J Oral Sci 2010;118:290-297.

13. Mccaul LK, Mchugh S, Saunders WP. The influence of specialty training and experience on decision making in endodontic diagnosis and treatment planning. Int Endod J 2001;34:594-606.

14. Nascimento GG, Correa MB, Opdam N, Demarco FF. Do clinical experience time and postgraduate training influence the choice of materials for posterior restorations? Results of a survey with Brazilian general dentists. Braz Dent J 2013;24:642-646.

15. Demarco FF, Baldissera RA, Madruga FC, Simoes RC, Lund RG, Correa $M B$, et al.. Anterior composite restorations in clinical practice: findings from a survey with general dental practitioners. Journal of Applied Oral Science 2013;21:497-504.

16. Demarco FF, Conde MC, Ely C, Torre EN, Costa JR, Fernandez MR, et al.. Preferences on vital and nonvital tooth bleaching: a survey among dentists from a city of Southern Brazil. Braz Dent J 2013;24:527-531.

17. Marcenes W, Kassebaum NJ, Bernabe E, Flaxman A, Naghavi M, Lopez A, et al.. Global burden of oral conditions in 1990-2010: a systematic analysis. J Dent Res 2013;92:592-597.

18. Schwendicke $F$, Dorfer CE, Paris S. Incomplete caries removal: a systematic review and meta-analysis. J Dent Res 2013;92:306-314.

19. Zijlstra-Shaw S, Roberts TE, Robinson PG. Perceptions of professionalism in dentistry - a qualitative study. Braz Dent J 2013;215:E18.

20. Weber CM, Alves LS, Maltz M. Treatment decisions for deep carious lesions in the public health service in Southern Brazil. J Public Health Dent 2011;71:265-270.

21. Mickenautsch S, Yengopal V, Banerjee A. Pulp response to resinmodified glass ionomer and calcium hydroxide cements in deep cavities: A quantitative systematic review. Dent Mater 2010;26:761770.

22. Van De Sande FH, Da Rosa Rodolpho PA, Basso GR, Patias R, Da Rosa $\mathrm{QF}$, Demarco FF, et al.. 18-year survival of posterior composite resin restorations with and without glass ionomer cement as base. Dent Mater 2015;31:669-675.

23. Sarkis-Onofre R, Pereira-Cenci T, Opdam NJ, Demarco FF. Preference for using posts to restore endodontically treated teeth: findings from a survey with dentists. Brazilian Oral Research 2015;29:1-6.

Received July 16, 2015 Accepted October 28, 2015 